\title{
Pelatihan Penggunaan Google Forms dan Google Class Room Pada Guru SMP Dalam Pembelajaran di Masa Pandemi Covid-19
}

\author{
Adi Rosadi, Muh Hasan Marwiji, Jimatul Arrobi, Cecep Hilman, Eneng Yeni Mariah \\ STAI Sukabumi \\ adyrosady27@gmail.com
}

\begin{abstract}
ABSTRAK
Kemampuan guru dalam penggunaan teknologi dan komunikasi sangat penting. Kondisi pandemic memaksa guru harus meningkatkan kemampuannya guna membantu dalam pelaksanaan pembelajaran online. tujuan pengabdian kepada masyarakat yaitu memberkan pemahaman dan mampu mempraktikan google Forms dan class dalam proses pembelajaran. Bahan yang digunakan yaitu modul Adapun metode yang dipakai yaitu pendekatan teoritis dan prakis dengan menggunakan metode ceramah, diskusi dan praktik serta pendampingan. Hasil pengabdian kepada masyarakat kegiatan pelatihan membantu guru dalam melaksanakan tugasnya. Seluruh peserta yaitu 30 orang rata-rata sudah menahami dan mampu membuat google clas dan forms yang dijadikan sebagai alat proses media evaluasi Pembelajaran Jarak Jauh (PJJ) dan diikuti oleh peserta dengan antusias. Kesimpulannya adalah bahwa kegiatan pengabdian kepada masyarakat kegiatan pelatihan google class dan forms membantu proses pembelajaran
\end{abstract}

Kata kunci : Pelatihan, Pembelajaran, Daring

\begin{abstract}
The ability of teachers in the use of technology and communication is very important. Pandemic conditions force teachers to improve their skills to assist in the implementation of online learning. the purpose of community service is to know and be able to practice google Forms and classes in the learning process, the materials used are modules As for the methods used are theoretical and prakis approaches using methods of lectures, discussions and practices and mentoring. and methods of community service training activities help teachers in carrying out their duties. All participants, namely 30 people on average, have understood and been able to make google clas and forms that are used as a medium of evaluation of Distance Learning (PJJ) and followed by participants enthusiastically. The conclusion is that community service activities google class training activities and forms help the learning process.
\end{abstract}

Keywords : Training, Learning, Online 


\section{PENDAHULUAN}

Fenomena tetang pembatas jarak dan pemberlakuan bekerja dari rumah mempengaruhi situasi penerapan proses pembelajaran pada Pendidikan dimulai dari tingkat usia dini sampai dengan perguruan tinggi. Hal ini ditandai dengan lahirnya surat edaran kementrian Pendidikan dan kebudayaan tentang pelaksanaan kebijakan pada masa darurat. Dengan tujuan agar warga Pendidikan melaksanakan pembelajaran dari rumah.

Akan tetapi, masalah yang muncul adalah kesiapan guru dalam menghadapi fenomena tersebut belum sepenuhnya siap. Diantaranya adalah proses pembelajaran yang asalnya tatap muka menjadi dari. Penggunaan teknologi adalah salah satu kendalanya.

Pada dasarnya pembelajaran dari meruakan bagian dari pemenuhan hak dan keajiban sekolah dalam pemenuhan psikosisoal bagi siswa, guru, dan orantua.(Utanto \& Dewanti, 2020). Akan tetapi, proses pembelajaran daring meninbulkan ternt baru yaitu dimana teknologi menjadi sarana atau wadah, tempat dalam mencapai tujuan pendikan. Kesiapan akan penggunaan aplikasi pembelajaran dalam proses pembelajaran merupakan bagian yang tidak bisa terpisahkan.

Untuk mengatasi kendala tersebut dibuthkan sebuah upaya yang perlu dilakukan kepada guru dalam mempersiapkan guru siap dalam menghadapi pembalajaran daring. Salah satu upaya yang dilakukan yaitu dengan melakukan pelatihan dan pendampingan kepada guru terkait penggunaan aplikasi pendidikan yang murah dan terjangkau.

Prosespendampingan dan pelatihan diperlukan olah guru dalam menghadapi pembelajaran jarak jauh. Salah satu aplikasi yang dapat dimanfaatkan yaitu google Class dan google Forms.

Google Classroom dan google forms dapat menjadi salah satu solusi yang digunakan kaena dengan penggunaan aplikasi ini siswa dan guru dapat mengakses pembelajaran kapanpun dan dimanapun tanpa adanya Batasan waktu.(Nurhusna, 2020)

Aplikasi Google Form dan class adalah salah satu bagian dari google yang disediakan dan dapat membantu proses pembelajaran dan juga kaitannya dengan evaluasi pembelajaran terlebih lagi aplikasi ini merupakan aplikasi yang tidak berbayar atau gratis. (Batubara, 2016)

Salah satu tujuan dalam pengabdian kepada masyarakat dengan melakukan penggunaan google forms dan class room pada guru SMP dalam pembelajaran di masa pandemi covid-19 yaitu agar guru mampu menerapkan dan memanfaatkan aplikasi ini dalam pembelajaran daring.

\section{BAHAN DAN METODE}

Pelatihan penggunaan google forms dan class room pada guru SMP dalam pembelajaran di masa pandemi covid-19 ini dilaksanakan pada tanggal 7 Desember 2020 mulai pukul $08.00 \mathrm{~s} / \mathrm{d}$ selesai WIB dengan media pelaksanaan melalui Zoom Meeting (SDN CIMANGGU 1). 
Adapun dalam kegiatan ini peserta yang mengikuti yaitu berjumlah 30 peserta. Sedangkan metode yang dipakai yaitu diskusi dan ceramah. Bahan yang dipakai yaitu Power Point dan web Google Class dan forms. Untuk mengkur keberhasilan proses pelatihan pada kegiatan ini mengggunakan Pre-Test dan Post-Test yang disebarkan dengan aplikasi google froms.

\section{HASIL}

Proses kegiatan Pengabdian kepada masyarakat pada tahap pertama diawali dengan kegiatan pembukaan dan sambutan dari penyelenggara. Sedangkan pada tahap selanjutnya dalah tahap pemberian materi yang membahasa tentang pentingnya aplikasi Pendidikan dan sampai pada proses penggunaan dan pendampinga dalam membuat Google Class dan forms.

Pada tahap proses pelaksanaan audiens sangat antuasias sekali hal ini ditandai dengan beberap pertanyaan-pertanyaan tentang bagaimana penggunaan aplikasi Google Class dan forms.

Tahap proses pendampingan dilakukan dengan menuntun guru dimulai dari Langkahlangkah awal bagaimana membuat Google Class. Pemateri mendapingi peserta dalam penggunaan lepotop dan juga pemanfaatan handphone dalam proses pembuatan Google Class.

Adapun langkah-langkah Google Class dijelaskan secara rinci oleh pematari. Adapun terkait penggunan Google forms diawali dengan pemberian bagaimana manfaat dan juga tahap-tahap sampai pada proses pendamingan pembuatan Google forms.

Pemateri dalam kegiatan pelatihan menyediakan dan memberikan materi atau modul tentang tata cara penggunaan google class dan forms kepada peserta. Praktik dilaksanakan dengan tahap-tahap proses pembuatan pemberian contoh yaitu membuat soal pada google form dan membagikannya kedalam Google class.

Simulasi berjalan dengan lancer tanpa adanya kendala kegiatan pendampingan guru dilakukan dengan penuh kekeluargaan dan juga menjunjung tinggi semnagat kebersamaan.

Adapun saat simulasi selesai dilakukan, guru diberikan tugas untuk membuat google Forms dan class. Pada kegiatan akhir pula dilakukan tanya jawab Kembali dan menanyakan akan kendala yang dialami oleh peserta.

Adapun kegiatan evaluasi Kegiatan Pengabdian Masyarakat dilakukan dengan memberikan link kuesioner kepada 30 peserta yang selanjutnya dijadikan acuan sebagai kuatlitas kegiatan dan menjadi umpat balik. Adapun keriteria yang digunakan yaitu 1) Sangat Kurang 2) Kurang 3) Cukup, 4) Baik, dan 5) sangat Baik.

\section{PEMBAHASAN}

Pertumbuhan teknologi data terus semakin pesat dan ini tidak dapat dihindari oleh dunia Pendidikan khusunya oleh guru. Tuntutan pertumbuhan teknologi juga merupakan sebuah upaya yang dilakukan 
dalam meningkatkan kualitas pembelajaran pada sistem pendidikan.

Kompetensi dalam penggunaan teknologi rupanya menjadi kewajiban yang diperlukan guru dalam masa pandemic. Terlebih lagi saat kegiatan pembelajaran jarak jauh.

Google class merupakan aplikasi tak berbayar, sehingga google class dianggap sangat cocok untuk digunakan dinegaranegara berkembang, atau secara khusus dapat digunakan oleh sekolah-sekolah yang miliki keterbatasan biaya dalam pengembangan pengunaan ICT dalam proses pembelajarannya. google class juga dapat digunakan sebagai alat untuk mengatur sistem pembelajaran ditingkat sekolah sampai perguruan tinggi.(Ula Nisa El Fauziah Lilis Suryani, 2019)

Ada bebrpa manfaat yang dirasakan dari kegiatan penggunaan google froms yaitu membantu guru dalam menganalisis dan menghasilkan hasil yang cepat dan digambarkan dengan diagram, dpat diakses dimanapun dan kapanpun secara Bersamasama oleh siswa, proses distrubus dan tabulasi data terjadi real-time dan data yang ada tersimpan dengan aman dan guru dapat mengunduhnya kapanpun. Aplikasi ini juga aman dalam menyimpan berkas dan tidak rentan dengan virus.

Pembelajatan online bermanfaat terhadap aktivitas pendidikan di kelas (classroom instruction), yaitu sebagai suplemen, bagi siswa untuk kapan dan dimanapun mengakses modul-modul pembelajaram, komplemen aplikasi ini juga bisa digunakan dalam proses pengayaan dan remedia bagi siswa, dan siswa dapat mengundur lebar tugas dan materi serta mengirimnya kembali .(Anugrahana, 2020)

Proses kegiatan pengabdian kepada masayarakat ini merupakan bagian dari bentuk mempasitasi guru dalam proses pembelajaran jarak jauh. Adapun kelebihan dari penggunaan aplikasi ini adalah proses lebih praktis, fleksibel bisa dimanapun dan kapaun pun. Mengirit waktu, mudak menganalisis nilai mengunakan Google Form, dapat dipantau dan didampingi oleh orang tu, dan guru dan siswa mendapatkan pengalaman baru.

Sejalan dengan hasil pengabdian ini, hasil penelitian yang pernah dilakukan oleh (Iqbal et al., 2018) juga menunjukkan bahwa penggunaan google form dapat dijadikan sebagai media pembelajaran.

Penelitian tentang pembuatan googleformini juga pernah dilakukan oleh (Batubara, 2016) yang menunjukkan bahwa google forms dijadikan sebagai media yang cukup efektif untuk menilai kinerja dosen.

Berdasarkan hasil penelitian oleh (Salamah, 2020) bahwa penggunaan aplikasi google classroom juga efektif dalam penyampaian materi maupun pengumpulan tugas karema tidaklah menggunakan alat tulis. Setiap guru dapat dengan mudah mengupload power point, video maupun soal-soal dengan menggunakan google classroom. 


\section{KESIMPULAN DAN SARAN}

Berdarkaan hasil kegiatan pengambdian kepada masyarakat dapat disimpulkan bahwa kegiatan pelatihan membantu guru dalam melaksanakan tugasnya. Seluruh peserta yaitu 30 orang rata-rata sudah menahami dan mampu membuat google clas dan forms yang dijadikan sebagai alat proses dan evaluasi Pembelajaran Jarak Jauh (PJJ).

\section{UCAPAN TERIMA KASIH}

Ucapan terima kadis kami sampaikan kepada Lembaga Pengabdian dan Penelitian kepada Masyarakat (LPPM) STAI Sukabumi yang telah memonitor kegiatan pengabdian kepada Masyarakat. Dan juga kepada seluruh dewan guru yang telah berpartisipasi dalam kegaiatan kegiatan pengabdian kepada Masyarakat.

\section{DAFTAR PUSTAKA}

Anugrahana, A. (2020). Hambatan , Solusi dan Harapan: Pembelajaran Daring Selama Masa Pandemi Covid-19 Oleh Guru Sekolah Dasar. Scholaria: Jurnal Pendidikan Dan Kebudayaan, 10, 282 289.

Batubara, H. H. (2016). PENGGUNAAN GOOGLE FORM DI PRODI PGMI UNISKA MUHAMMAD ARSYAD AL BANJARI. AL-BIDAYAH: Jurnal Pendidikan Dasar Islam, 8(2).

Hayati, A. S. (2020). Peran Orang Tua dalam Meningkatkan Motivasi Belajar Anak Dengan Sistem Daring pada Masa Pandemi di Desa Depokrejo, Kebumen Arifia Sabila Hayati. Tasyri, 2, 23-32.

Iqbal, M., Amal, B. K., \& Rumapea, M. E. (2018). Penggunaan Google Forms Sebagai Media Pemberian Tugas Mata Kuliah Pengantar Ilmu Sosial. Jurnal Pendidikan Ilmu-Ilmu Sosial, 10(1), 120-127.

Nurhusna, N. (2020). Google Classroom sebagai Media Pembelajaran pada Mata
Kuliah Teks Bahasa Indonesia. Prosiding Seminar Daring Nasional: Pengembangan Kurikulum Merdeka Belajar Program Studi Pendidikan Bahasa Indonesia, 21 Oktober 2020, 5257.

Salamah, W. (2020). Deskripsi Penggunaan Aplikasi Google Classroom dalam Proses Pembelajaran. Jurnal Penelitian Dan Pengembangan Pendidikan, 4, 533538.

Ula Nisa El Fauziah Lilis Suryani, T. S. (2019). PENERAPAN GOOGLE CLASSROOM

DALAM PEMBELAJARAN BAHASA INGGRIS KEPADA GURU-GURU BAHASA INGGRIS SMP DI SUBANG. Jurnal Pengabdian Kepada Masyarakat (Abdimas) IKIP Siliwangi, 02, 183-191.

Utanto, Y., \& Dewanti, S. S. (2020). Analisa Pemanfaatan Teknologi Informasi dan Komunikasi Sebagai Media Pembelajaran Anak Usia Dini di Masa Pandemi Covid -19. SEMINAR NASIONAL PASCASARJANA 2020. 